\title{
Institutional analysis in scientific health production: an integrative literature review
}

\author{
A análise institucional na produção científica em saúde: \\ uma revisão integrativa de literatura \\ El análisis institucional en la producción científica en \\ salud: una revisión integradora de literatura
}

How to cite this article:

Kasper M, Fortuna CM, Braghetto GT, Marcussi TC, Feliciano AB, L'Abbate S. Institutional analysis in scientific health production: an integrative literature review. Rev Esc Enferm USP. 2020;54:e03587. doi: https://doi.org/10.1590/S1980-220X2018046203587

\section{Maristel Kasper ${ }^{1}$ \\ Cinira Magali Fortuna ${ }^{1}$ \\ Gláucia Tamburú Braghetto ${ }^{2}$ \\ Thalita Caroline Marcussi ${ }^{3}$ \\ Adriana Barbieri Feliciano ${ }^{4}$ \\ Solange L'Abbate ${ }^{5}$}

${ }^{1}$ Universidade de São Paulo, Escola de Enfermagem de Ribeirão Preto, Programa de Pós-Graduação Enfermagem em Saúde Pública, Ribeirão Preto, SP, Brazil.

${ }^{2}$ Universidade de Ribeirão Preto, Ribeirão Preto, SP, Brazil.

${ }^{3}$ Universidade de São Paulo, Escola de Enfermagem de Ribeirão Preto, Ribeirão Preto, SP, Brazil.

${ }^{4}$ Universidade Federal de São Carlos, Departamento de Enfermagem, São Carlos, SP, Brazil

${ }^{5}$ Universidade Estadual de Campinas, Departamento de Saúde Coletiva, Campinas, SP, Brazil.

\begin{abstract}
Objective: To analyze the use of the Institutional Analysis theoretical-methodological framework and of the central concept of institution in its three moments - instituted, instituting and institutionalizing in health studies. Method: Integrative review conducted in databases of PubMed/Medline, LILACS, Scopus, and CINAHL including original research articles published between 2012 and 2017. Results: Analysis of 26 publications. A plurality of study objects was found, and the most common were related to collective health, namely: mental health, violence, family-team relationship, family health, primary care, health of women, children and adolescents, oral health, continuing education, micropolitics of health work, health surveillance, HIV, law, pedagogical practices, school education and Autism. Nursing and psychology were the areas that most opted for Institutional Analysis. The polysemy of the institution concept was confirmed in the findings, indicating the richness of modes and uses of the concepts. Conclusion: Institutional Analysis presents tool-concepts to perform analyzes of health practices consistent with the Unified Health System.
\end{abstract}

\section{DESCRIPTORS}

Institutional Analysis; Organizations; Public Health; Investigative Techniques; Review.
Corresponding author:

Maristel Kasper

Rua César Tupinambá Roselino, 334, Apto 18, Bairro Jardim Ana Maria CEP 14023-260 - Ribeirão Preto, SP, Brazil mkasper@usp.br
Received: 10/31/2018 Approved: 09/25/2019 


\section{INTRODUCTION}

Institutional Analysis is a theoretical-methodological framework derived from the social sciences and built from the dialogue between different disciplines and fields of knowledge - law, economics, sociology, psychology and anthropology - and theoretical frameworks - philosophy of law, Marxism, psychoanalysis, psychosociology, psychopedagogy and institutional pedagogy $y^{(1)}$. The social and historical genesis of Institutional Analysis (IA) was in the 1960s in France, marked by the dissatisfaction of a large part of French society with the role of some organizations, namely of students with the university, workers with companies, families with schools, the society in general with politics and the care of psychiatric hospitals, among others. Unions and parties supported this general dissatisfaction, culminating in a wide-ranging protest movement in May $68^{(1-}$ ${ }^{4}$. Although student mobilization has suffered strong police repression since the beginning, in a short time the movement expanded, paralyzed $2 / 3$ of the country's activities and led to the resignation of the president of the time and the holding of new elections. Although the demands questioned conservatism in politics, economics, education, culture and the arts, and proposed wide-ranging structural changes, after May 68,"a paradoxical presence of a posteriori prophecies is established in France", and existed a line that "led agitations of May towards calm waters" and another that "prefers storms to the calm" ${ }^{\text {"(3) }}$.

In this context of crisis and ruptures, the gap between the expected role of institutions - education, work, politics, health - and the role played by them in society became evident. In 1970, the French sociologist René Lourau published the book Institutional Analysis, based on his doctoral thesis defended in 1969 at the University of Nanterre. He proposed the concept of institution from the dialectical relationship between three moments - instituted, instituting and institutionalization - removing any notion of institution as something static. Lourau differentiates institution from establishment and organization by emphasizing the immaterial dimension of the whole institution ${ }^{(1)}$. Also important for this field was the publication, in 1972 in Brazil, of the book Chaves da Sociologia (Sociology Keys)(2). The work 'Institutional Analysis' had its first Brazilian edition in 1975.

In addition to the aforementioned concept of institution, the following are concepts proposed by IA: implication, analyzer, transversality, self-management, self-analysis, resistance, order and demand, restitution and transduction ${ }^{(1-2)}$. Institutional Analysis can be used for "paper analysis" based on the analysis of documents, interviews and observations and as an intervention practice, the Socioanalysis. Within the scope of IA, the socio-historical approach is also considered, which has as its object the investigation of historical realities of the past that relate to the present. In recent years, the Institutional Socioclinic has developed, derived from Socioanalysis. In addition to this aspect, Schizoanalysis is also present in Brazil ${ }^{(5)}$.

In this country, the IA was inserted in the 1970s, initially with the Departments of Psychology of some public universities and in different research groups, although the articulation of IA with Health and Public Health would only take place in the $2000 s^{(4)}$. Both areas found concepts in the theoretical-methodological contribution of IA that enabled a better understanding of situations experienced in the health service routine, and contributed to increase the capacity to analyze such situations and intervene in them ${ }^{(4)}$. In addition to academic research based on this framework, some IA concepts such as transversality, self-analysis, self-management, devices, and subjects' protagonism inspired the theoretical framework of some public policies of the Unified Health System (SUS - Sistema Único de Saúde), such as the National Policy Humanization and the National Policy for Permanent Education in Health.

Some scholars ${ }^{(4)}$ mention that the history of IA in Brazil has not yet been told, as very little is known about its insertion, particularly in the area of health, and even less about the way it is offered in universities, private or philanthropic organizations. Furthermore, the form how concepts are articulated with the daily practice of health services is also little explored, among other forms of intervention and analysis, and "an investigation of these texts based on descriptors would be very relevant to deepen the study of IA in Brazil"(4). For these reasons and to understand the concepts of IA as a tool-concept capable of operating social practices, among them, health practices, this integrative literature review was performed to know the current scenario of scientific production with this theoretical framework.

By taking into account the fundamental concept of IA, the Institution, and always considering its three moments Instituted, Instituting and Institutionalization - this study was conducted with the purpose of obtaining answers to the following questions: 1) Which objects of studies in the field of health have been using Institutional Analysis? 2) How is the concept of institution and its three moments - instituted, instituting, institutionalization - used in these studies? 3) Which areas of health use the concept and its three moments? 4) Which journals were chosen for the publication of these studies? 5) How has the concept and its three moments been used in health research? Thus, the objective of this study was to analyze the use of the theoretical-methodological framework of AI and the central concept of institution in its three moments - institution, instituted, instituting, institutionalization in studies in the health area.

\section{METHOD}

\section{TyPe OF STUDY}

The integrative review consists of a "type of literature review that brings together findings from studies developed using different methodologies, allowing researchers to synthesize results while respecting the epistemological affiliation of the empirical studies included". This type of analysis requires that reviewers evaluate and synthesize primary data in a systematic and rigorous manner ${ }^{(6)}$. Among the various purposes of developing an integrative review, according to a study of this type performed in 2014, this is a "form of research that allows to review, criticize and synthesize representative literature on a topic or subject in an integrated manner that can generate new approaches and perspectives on the revised subject"(6). 


\section{Data COlleCtion}

Based on the objective of this study, a search for Health Sciences Descriptors (DeCS) was carried out to select the most suitable for this purpose. The present review was carried out in databases of Pubmed/Medline, LILACS, Scopus and CINAHL with controlled and uncontrolled descriptors. The controlled descriptor "Health" and the uncontrolled descriptors, "Institutional Analysis", "Socioanalysis", "Schizoanalysis", and "Socioclinic" in Portuguese and English were used. The Boolean operators OR and AND were used to combine these descriptors.

Next, the following inclusion criteria were used for the selection of studies: a) original research articles, b) available in full version, c) published in the 2012-2017 period, in Portuguese, French, Spanish and English , d) belonging to the health area, according to the list of professions indicated by the Ministry of Health ${ }^{(7)}$. Initially, the definition of the search period was based on the pioneering publication on the topic in Brazil $^{(4)}$, the collection Institutional Analysis in Brazil (Análise Institucional no Brasil), by Saidón \& Kamkhagi (1987) that completed 30 years in 2017. However, due to the significant number of studies found, the search was redefined for the last five years, remaining from 2012 to 2017.

One defined the following exclusion criteria: a) studies in which the approach to IA was not the central theoretical-methodological option of the study in the results and conclusions; $\mathrm{b}$ ) studies that presented interventions in IA as in training at institutional level, c) experience reports, notes, reflection articles, dissertations, theses, public policies and videos. The search in databases took place between November 1 and 6, 2017, using an advanced form.

The search strategy used was (saúde or health) AND ("análise institucional” OR "institutional analysis" OR socioclinica OR socioclinic OR socioanálise OR socioanalysis OR esquizoanálise OR schizoanalysis) in the field "words" and AND (2012 or 2013 or 2014 or 2015 or 2016 or 2017), in the field "country, year of publication". After identification, studies were selected according to the guiding question and the inclusion and exclusion criteria previously defined. The instrument was designed with the purpose of extracting and analyzing data from the included studies. It was composed of the following items: 1- identification of the article; 2presence or not of the concept of institution, considering its three moments - instituted, instituting and institutionalization; 3- authors who used the concept; 4- objects of study.

In the study, 450 articles were found in PubMed/Medline, 18 in LILACS, 138 in Scopus, and 18 in CINAHL. The stages of study selection comprised the identification, screening, eligibility and inclusion, totaling 26 publications $^{(8-33)}$ that met the defined criteria, as explained in the analysis flowchart (Figure 1).

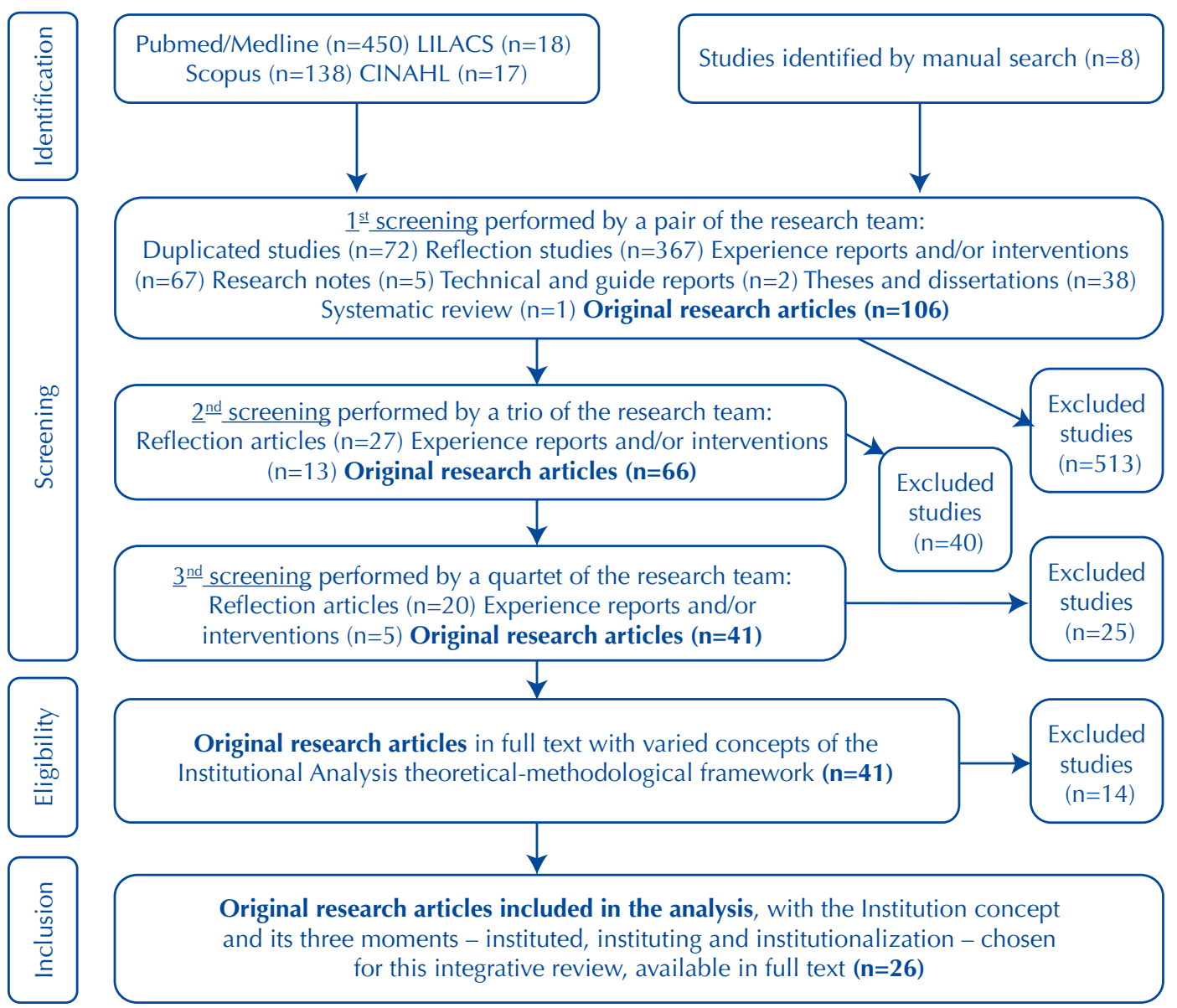

Figure 1 - Flowchart of the study selection process for the integrative review - Ribeirão Preto, SP, Brazil, 2018. 


\section{DATA ANALYSIS AND PROCESSING}

Categorization was the form adopted for the analysis of results related to the concept of institution and its three moments - instituted, instituting and institutionalization as explained above. Such categorization provided the grouping by similarities and/or conceptual approximation, as shown in Chart 2. The work of analyzing and integrating the concepts consisted of a delicate and complex task, which was transformed while appeared the plural forms of functioning of concepts that required numerous resumptions and re-analyzes of studies. One chose to present the results by means of sequential tables that show how the concept of institution (always considering the three moments that compose it) was used by the authors and how it dialogued with the study objects.

The interest was to know and characterize the scenario of studies, and highlight the various possibilities taken by researchers according to their investigated object. The choice was to keep distance from the perspective of analysis focused on a single perspective of addressing these concepts, and in this sense, the polysemy of concepts was explored, as well as their approximations and divergences for the different authors.

\section{RESUITS}

The articles were published in 19 different journals in the areas of psychology, nursing, public health and education, as shown in Chart 1. Regarding the year of publication, years 2012 and 2013 presented $26.9 \%$ of articles (7) each, followed by the distribution: $7.7 \%$ (2) in 2014; $23 \%$ (6) in $2015 ; 11.5 \%$ (3) in 2016; 3.8\% (1) in 2017. In relation to language, most studies were published in Portuguese, in addition to one in Spanish $^{(27)}$ and two in French ${ }^{(28,32)}$.

The contexts of studies were quite varied and linked to the following themes: Violence, Family-team relationship, Family Health, Parenting, Primary Care, Health of Women, Children and Adolescents, Mental Health, Oral Health, Training and Permanent Education, Micropolitics of the Process of Health Work, Health Surveillance, HIV, Law, Pedagogical Practices, Production of Scientific Knowledge in Postgraduate Studies, School Education and Autism, as shown in Chart 2.

Chart 1 - Journals chosen for publication of the studies - Ribeirão Preto, SP, Brazil, 2018.

\begin{tabular}{|c|c|c|}
\hline Authors & Journal & Frequency \\
\hline $\begin{array}{c}\text { Romagnoli RC, Magnani NR, } 2012^{(8)} \\
\text { Fortuna CM, Monceau G, Valentim S, Mennani KLE, 2014 } \\
\text { Romagnoli RC, } 2015 \mathrm{a}^{(3)}\end{array}$ & Fractal: Revista de Psicologia (UFF) & $12.1 \%$ \\
\hline $\begin{array}{l}\text { Pezzato LM, L'Abbate S, 2012(11) } \\
\text { Archanjo AM, Schraiber LB, 2012 }\end{array}$ & Saúde e Sociedade (USP) & \multirow{5}{*}{$7.7 \%$} \\
\hline $\begin{array}{l}\text { Pezzato LM, L'Abbate S, Botazzo C, } 2013^{(17)} \\
\text { Sanches ICP, Couto IRR, Abrahão AL, Andrade M, 2013 }\end{array}$ & Ciência \& Saúde Coletiva (ABRASCO) & \\
\hline $\begin{array}{l}\text { Gontijo TL, Xavier CC, Freitas MIF, 2012 } \\
\text { Fortuna CM, Mesquita LP, Matumoto S, Monceau G, } 2016^{(30)}\end{array}$ & Cadernos de Saúde Pública (FIOCRUZ) & \\
\hline $\begin{array}{l}\text { Garcia RA, L'Abbate S, } 2015^{(24)} \\
\text { Dóbies DV, L'Abbate S, } 2016^{(31)}\end{array}$ & Saúde em Debate (CEBES) & \\
\hline $\begin{array}{c}\text { Muniz MP, Tavares CMM, 2012 } \\
\text { Silva AB, Gomes BCF, Torres OM, Siniak DS, 2013 }\end{array}$ & $\begin{array}{l}\text { Revista de Pesquisa: Cuidado é Fundamental Online } \\
\text { (UNIRIO) }\end{array}$ & \\
\hline Zambenedetti G, Silva RAN, $2015^{(29)}$ & Estudos de Psicologia (Natal) (UFRN) & \multirow{13}{*}{$3.8 \%$} \\
\hline Garcia RA, L'Abbate S, Arakaki J, 2015 $5^{(27)}$ & Interface (Botucatu) (UNESP) & \\
\hline Pereira WR, Ribeiro MRR, Santos NC, Depes VBS, $2012^{(14)}$ & Acta Paulista de Enfermagem (UNIFESP) & \\
\hline $\begin{array}{l}\text { Fortuna CM, Matumoto S, Camargo-Borges C, Pereira, MJB, Mishima } \\
\qquad \text { SM, Kawata LS et al., 2012 }\end{array}$ & Revista da Escola de Enfermagem da USP (USP) & \\
\hline Depes VBS, Pereira WR, 2013 ${ }^{(20)}$ & Revista Gaúcha de Enfermagem (UFRGS) & \\
\hline Romagnoli RC, 2015b $b^{(25)}$ & Barbarói (UNISC) & \\
\hline Lima AIO, Severo AK, Andrade NL Soares GP, Silva LM, 2013 & Temas em Psicologia (SBP) & \\
\hline Silveira L, Nunes MO., 2013 ${ }^{(18)}$ & Polis e Psique (UFRGS) & \\
\hline $\begin{array}{l}\text { Zambenedetti G, Piccinini CA, Sales ALLF, Paulon SM, Silva RAN, } \\
2014^{(23)}\end{array}$ & Psicologia: Ciência e Profissão (CFP) & \\
\hline Silva DCR, $2015^{(26)}$ & Psicologia da Educação (PUC/SP) & \\
\hline Barreto L, Dimenstein M, Leite JF, $2013^{(13)}$ & Athenea digital (UAB/Spain) & \\
\hline $\begin{array}{l}\text { Passos ICF, Vieira K, Moreira L, Rodrigues F, Amorim M, Santos C et. } \\
\text { al., 2017(32) }\end{array}$ & Santé Mentale au Québect - Érudit (EdeM/Canada) & \\
\hline Spagnol CA, L'Abbate S, Monceau G, Jovic L, 2016 & Recherche en Soin Infirmiers (Cairn/France) & \\
\hline
\end{tabular}


Chart 2 - Object/Question/Objective of the study, Type of study, Techniques and/or Tools, Data analysis - Ribeirão Preto, SP, Brazil, 2018.

\begin{tabular}{|c|c|c|c|}
\hline Object/Question/Objective of the study & Type of study & $\begin{array}{l}\text { Techniques } \\
\text { and/or Tools }\end{array}$ & Data analysis \\
\hline $\begin{array}{l}\text { To configure and problematize the relationships in the team-family territory and show } \\
\text { what makes the effective family participation difficult in the treatment of children } \\
\text { attended at the Renato de Avelar Azeredo Psychopedagogical Center (Portuguese } \\
\text { acronym: CPP) of the Municipality of Nova Lima }{ }^{(8)} \text {. }\end{array}$ & $\begin{array}{l}\text { Intervention } \\
\text { research } \\
\text { Cartography }\end{array}$ & $\begin{array}{l}\text { Semi-structured } \\
\text { interview, } \\
\text { Observation, General } \\
\text { assemblies }\end{array}$ & $\begin{array}{l}\text { Institutional } \\
\text { analysis }\end{array}$ \\
\hline To investigate violence against women in Montes Claros, Minas Gerais ${ }^{(9)}$. & $\begin{array}{l}\text { Qualitative and } \\
\text { quantitative } \\
\text { research }\end{array}$ & $\begin{array}{l}\text { Document analysis } \\
\text { Participant } \\
\text { observation }\end{array}$ & $\begin{array}{l}\text { Schizoanalysis } \\
\text { SPSS }\end{array}$ \\
\hline $\begin{array}{l}\text { To map the instituted and instituting movements in the work of the Family Health } \\
\text { Strategy with regard to the composition of their care practices }{ }^{(10)} \text {. }\end{array}$ & $\begin{array}{l}\text { Intervention } \\
\text { research }\end{array}$ & Group meetings & Schizoanalysis \\
\hline $\begin{array}{l}\text { To present the methodological strategy produced and exercised during the development } \\
\text { of a doctoral research in which the theoretical-methodological framework of Institutional } \\
\text { Analysis in Collective Health was adopted }{ }^{(11)} \text {. }\end{array}$ & $\begin{array}{l}\text { Action- } \\
\text { intervention } \\
\text { research }\end{array}$ & $\begin{array}{l}\text { Diary, Discussion } \\
\text { groups }\end{array}$ & Socioanalysis \\
\hline $\begin{array}{l}\text { To study the performance of psychologists in Health Centers (Portuguese acronym: UBS - } \\
\text { Unidade Básica de Saúde) }\end{array}$ & $\begin{array}{l}\text { Qualitative } \\
\text { research }\end{array}$ & $\begin{array}{l}\text { Semi-structured } \\
\text { interview }\end{array}$ & $\begin{array}{l}\text { Content } \\
\text { analysis }\end{array}$ \\
\hline $\begin{array}{l}\text { To discuss the care offered to women in situations of violence with mental disorders and/or } \\
\text { treated at the psychosocial care network (Portuguese acronym: RAPS) in two agencies that } \\
\text { make up the care network for women: Reference Center and Shelter Home }{ }^{(13)} \text {. }\end{array}$ & $\begin{array}{l}\text { Intervention } \\
\text { research }\end{array}$ & $\begin{array}{l}\text { Semi-structured } \\
\text { interview }\end{array}$ & $\begin{array}{l}\text { Institutional } \\
\text { analysis }\end{array}$ \\
\hline $\begin{array}{l}\text { To know the pedagogical practices developed in the teaching of undergraduate Nursing } \\
\text { courses for the identification and analysis of those that promote subjectification processes } \\
\text { which reinforce students' desire to learn }\end{array}$ & $\begin{array}{l}\text { Qualitative } \\
\text { research }\end{array}$ & $\begin{array}{l}\text { Semi-structured } \\
\text { interview } \\
\text { Focus group }\end{array}$ & $\begin{array}{l}\text { Institutional } \\
\text { analysis }\end{array}$ \\
\hline $\begin{array}{l}\text { To understand the difficulties and facilities for the implementation of the Kangaroo Method } \\
\text { in Brazilian maternities with training by the Ministry of Health, from the perspective of } \\
\text { health professionals, managers and mothers of low birth weight newborns treated in these } \\
\text { services }^{(15)} \text {. }\end{array}$ & $\begin{array}{l}\text { Qualitative } \\
\text { research }\end{array}$ & $\begin{array}{l}\text { Semi-structured } \\
\text { interview }\end{array}$ & $\begin{array}{l}\text { Grounded } \\
\text { Theory }\end{array}$ \\
\hline $\begin{array}{l}\text { To analyze the nursing team's understanding of the educational processes experienced } \\
\text { by them in a psychiatric hospital }\end{array}$ & $\begin{array}{l}\text { Exploratory, } \\
\text { qualitative } \\
\text { research }\end{array}$ & $\begin{array}{l}\text { Participant } \\
\text { observation }\end{array}$ & $\begin{array}{l}\text { Institutional } \\
\text { analysis }\end{array}$ \\
\hline $\begin{array}{l}\text { To reflect on the effects and meanings provoked by an instituting proposal put under } \\
\text { analysis by a group of oral health professionals working in primary health care in the city } \\
\text { of Campinas (state of São Paulo) }\end{array}$ & $\begin{array}{l}\text { Socioanalytical } \\
\text { Intervention }\end{array}$ & Diary & Socioanalysis \\
\hline $\begin{array}{l}\text { To put into analysis the modes of subjectification of madness through the experiences } \\
\text { of users of a Psychosocial Care Center (in Portuguese CAPS) in Pentecostal religions by } \\
\text { identifying possible articulations between these institutions }{ }^{(18)} \text {. }\end{array}$ & $\begin{array}{l}\text { Qualitative } \\
\text { research } \\
\text { Ethnography }\end{array}$ & $\begin{array}{l}\text { Semi-structured } \\
\text { interview } \\
\text { Participant } \\
\text { observation }\end{array}$ & $\begin{array}{l}\text { Discourse } \\
\text { analysis }\end{array}$ \\
\hline $\begin{array}{l}\text { To know the perception and difficulties experienced in the exercise of hospital follow- } \\
\text { up in surgical inpatient units of a public hospital in the city of Niterói (state of Rio de } \\
\text { Janeiro) from the perspective of the inpatient and discuss them in the light of the concepts } \\
\text { of Institutional Analysis }(\mathrm{IA})^{(19)} \text {. }\end{array}$ & $\begin{array}{l}\text { Qualitative } \\
\text { research } \\
\text { Descriptive } \\
\text { research }\end{array}$ & $\begin{array}{l}\text { Semi-structured } \\
\text { interview } \\
\text { Observation }\end{array}$ & $\begin{array}{l}\text { Content } \\
\text { analysis }\end{array}$ \\
\hline $\begin{array}{l}\text { To understand how the training process in the Master in Nursing contributed to the } \\
\text { mobilization of formal and political aspects of scientific knowledge by graduates working in } \\
\text { health services }{ }^{(20)} \text {. }\end{array}$ & $\begin{array}{l}\text { Qualitative } \\
\text { research } \\
\text { Exploratory } \\
\text { research }\end{array}$ & $\begin{array}{l}\text { Semi-structured } \\
\text { interview }\end{array}$ & $\begin{array}{l}\text { Content } \\
\text { analysis }\end{array}$ \\
\hline To analyze the care provided by Family Health Teams to mental health users ${ }^{(21)}$. & $\begin{array}{l}\text { Qualitative } \\
\text { research }\end{array}$ & $\begin{array}{l}\text { Semi-structured } \\
\text { interview, Diary, } \\
\text { Participant } \\
\text { observation, Focus } \\
\text { Group }\end{array}$ & $\begin{array}{l}\text { Institutional } \\
\text { analysis }\end{array}$ \\
\hline $\begin{array}{l}\text { To present the concepts, perceptions and experiences brought by Mental Health } \\
\text { professionals in relation to their daily lives in services }\end{array}$ & $\begin{array}{l}\text { Qualitative } \\
\text { research }\end{array}$ & $\begin{array}{c}\text { Diary, Participant } \\
\text { observation, } \\
\text { Conversation group, } \\
\text { Questionnaire }\end{array}$ & $\begin{array}{l}\text { Categorized } \\
\text { results }\end{array}$ \\
\hline $\begin{array}{l}\text { To present an intervention study conducted with Community Health Agents from Family Health } \\
\text { Teams of a district management in the city of Porto Alegre (state of Rio Grande do Sul) }{ }^{223} \text {. }\end{array}$ & $\begin{array}{l}\text { Intervention } \\
\text { research }\end{array}$ & Discussion groups & $\begin{array}{l}\text { Not } \\
\text { mentioned }\end{array}$ \\
\hline $\begin{array}{l}\text { To analyze the institutionalization process of Health Surveillance in Campinas (state of } \\
\text { São Paulo) based on the theoretical-methodological framework of Institutional Analysis in } \\
\text { the socio-historical perspective }{ }^{(24)} \text {. }\end{array}$ & $\begin{array}{l}\text { Institutional } \\
\text { analysis }\end{array}$ & $\begin{array}{l}\text { Semi-structured } \\
\text { interview }\end{array}$ & $\begin{array}{l}\text { Socio- } \\
\text { historical }\end{array}$ \\
\hline $\begin{array}{l}\text { To investigate quantitatively and qualitatively the violent acts against women in the city } \\
\text { of Montes Claros, Minas Gerais }{ }^{(25)} \text {. }\end{array}$ & $\begin{array}{l}\text { Qualitative and } \\
\text { quantitative } \\
\text { research }\end{array}$ & $\begin{array}{l}\text { Document analysis - } \\
\text { occurrence reports }\end{array}$ & $\begin{array}{l}\text { Institutional } \\
\text { analysis } \\
\text { SPSS }\end{array}$ \\
\hline $\begin{array}{l}\text { To analyze the relationships based on (mis)encounters between health and education } \\
\text { workers, and the sources of tension between these professionals and the students' } \\
\text { families in the form of demands and referrals from the school }{ }^{(26)} \text {. }\end{array}$ & $\begin{array}{l}\text { Intervention } \\
\text { research } \\
\text { Socioanalysis }\end{array}$ & $\begin{array}{l}\text { Diary, Group } \\
\text { meetings, } \\
\text { Evaluation report }\end{array}$ & $\begin{array}{l}\text { Concepts of } \\
\text { the philosophy } \\
\text { of difference }\end{array}$ \\
\hline $\begin{array}{l}\text { Analizar y comprender cómo se realizan las acciones de Vigilancia en Salud en el municipio } \\
\text { de Moreno, cómo se articulan con los efectores de la Atención Primaria de la Salud, y qué } \\
\text { dispositivos se han implementado para que estos procesos se hagan efectivos }{ }^{(27)}\end{array}$ & $\begin{array}{l}\text { Qualitative } \\
\text { research }\end{array}$ & $\begin{array}{l}\text { Diary, Participant } \\
\text { observation }\end{array}$ & $\begin{array}{l}\text { Institutional } \\
\text { analysis }\end{array}$ \\
\hline
\end{tabular}




\begin{tabular}{|c|c|c|c|}
\hline Object/Question/Objective of the study & Type of study & $\begin{array}{l}\text { Techniques } \\
\text { and/or Tools }\end{array}$ & Data analysis \\
\hline $\begin{array}{l}\text { Décrire et analyser l'utilisation d'un dispositif socianalytique comme outil de collecte de } \\
\text { données dans une approche de recherche qualitative en sciences infirmières, ceci en } \\
\text { créant un espace pour l'analyse de la pratique professionnelle et des relations de travail, } \\
\text { auprès d'un groupe d'infirmières de l'Hôpital universitaire UFMG, Brésil/28) }\end{array}$ & $\begin{array}{l}\text { Qualitative } \\
\text { research } \\
\text { Intervention } \\
\text { research } \\
\text { Socioanalysis }\end{array}$ & $\begin{array}{l}\text { Analysis of } \\
\text { professional practices } \\
\text { Meetings } \\
\text { Questionnaire }\end{array}$ & $\begin{array}{c}\text { Institutional } \\
\text { analysis } \\
\text { Socioanalysis }\end{array}$ \\
\hline $\begin{array}{l}\text { Analysis of the paradoxical dimension of the territory and the processes of stigmatization } \\
\text { in access to HIV diagnosis in the context of Primary Health Care }{ }^{299} \text {. }\end{array}$ & $\begin{array}{l}\text { Analytical- } \\
\text { institutional } \\
\text { perspective }\end{array}$ & $\begin{array}{c}\text { Observation } \\
\text { Focus group } \\
\text { Restitution } \\
\end{array}$ & $\begin{array}{l}\text { Institutional } \\
\text { analysis }\end{array}$ \\
\hline $\begin{array}{l}\text { To analyze the involvement of researchers during the process of an intervention study } \\
\text { and the interferences caused by this analysis }{ }^{(30)} \text {. }\end{array}$ & $\begin{array}{l}\text { Qualitative } \\
\text { research, } \\
\text { Intervention } \\
\text { research }\end{array}$ & $\begin{array}{c}\text { Semi-structured } \\
\text { interview } \\
\text { Restitution, Meetings, } \\
\text { Researchers group, } \\
\text { Analysis workshop, } \\
\text { Notes } \\
\end{array}$ & $\begin{array}{l}\text { Institutional } \\
\text { analysis } \\
\text { Socioclinic }\end{array}$ \\
\hline $\begin{array}{l}\text { To analyze a resistance movement of a Collegiate Forum of Mental Health in Campinas } \\
\text { (state of São Paulo), where the current situation puts at risk its innovative history and the } \\
\text { care network in mental health because of the organizational stiffening and the tension } \\
\text { between the current municipal government and the partner entity in this area }{ }^{(31)} \text {. }\end{array}$ & $\begin{array}{l}\text { Qualitative } \\
\text { research }\end{array}$ & $\begin{array}{l}\text { Semi-structured } \\
\text { interview, Diary, } \\
\text { Participant } \\
\text { observation }\end{array}$ & $\begin{array}{l}\text { Institutional } \\
\text { Analysis } \\
\text { concepts }\end{array}$ \\
\hline $\begin{array}{c}\text { Contribuer au développement intersectoriel et interdisciplinaire du réseau local, } \\
\text { notamment du Sistema de Garantia dos Direitos Humanos da Criança e do Adolescente } \\
\text { (SGDHCA), pour faire face à des vulnérabilités psy-chosociales des enfants et des } \\
\text { adolescents, spécialement celles liées aux situations de violences sexuelles et à l'usage de } \\
\text { drogues }{ }^{(32)}\end{array}$ & $\begin{array}{l}\text { Critical action } \\
\text { Research } \\
\text { Cartography }\end{array}$ & Workshops & $\begin{array}{l}\text { Institutional } \\
\text { analysis } \\
\text { Schizoanalysis } \\
\text { Schizodrama }\end{array}$ \\
\hline $\begin{array}{l}\text { To present and discuss the production process of socioclinic research on parenting } \\
\text { developed in Gennevilliers, France, during } 2011 \text { and } 2012^{(33)} \text {. }\end{array}$ & $\begin{array}{l}\text { Intervention } \\
\text { research }\end{array}$ & $\begin{array}{c}\text { Participant } \\
\text { observation, } \\
\text { Restitution, } \\
\text { Discussion groups, } \\
\text { Informal interviews }\end{array}$ & $\begin{array}{l}\text { Institutional } \\
\text { analysis }\end{array}$ \\
\hline
\end{tabular}

Most studies conducted from this theoretical-methodological perspective were qualitative, given the nature of their study objects, as shown in Chart 2. The Institutional Analysis theoretical framework allows explaining how the objects of study are built, move and transform according to the political, economic, social and cultural scenario of their context, thereby constituting social constructions. The IA concepts contribute to visualize the modes of functioning of a given social reality by promoting a movement of complexification of analyzes and interventions.

Among the authors of the selected articles, there was prevalence of those in the areas of Psychology with $45.4 \%$ (25), followed by Nursing with $43.6 \%$ (24). In a smaller number was Medicine with 9\% (5), Dentistry with 5.4\% (3), Pedagogy with $1.8 \%$ (1) and Social Sciences with $1.1 \%$ (1). Two authors had more than one degree: one was graduated in Nursing and Medicine and the other in Law and Psychology.

The distribution of studies by region in Brazil was varied. The majority was from the Southeast region (23) (São Paulo-12, Minas Gerais-7, Rio de Janeiro-4), followed by the South region (4) (Paraná-2, Rio Grande do Sul-2), Northeast (2) (Natal-1, Rio Grande do Norte-2), Midwest (2) (Mato Grosso-2) and North region (0). Four articles included foreign authors: one from Argentina (27)(27) and three from France ${ }^{(28,30,33)}$.

In the studies analyzed, there was a multiplicity of IA concepts that supported the production of health knowledge. The most used concept was chosen to compose this integrative review, that is, the concept of institution, always considering its three moments - instituted, instituting and institutionalization - as shown in Chart 3.

Chart 3 - Definitions used for Institution - Instituted, Instituting and Institutionalization - Ribeirão Preto, SP, Brazil, 2018.

\begin{tabular}{|c|c|}
\hline AUTHORS & CONCEPT OF INSTITUTION \\
\hline \multicolumn{2}{|r|}{ INSTITUTION AS NORMS, RULES AND LAWS } \\
\hline $\begin{array}{c}\text { Fortuna, Matumoto, Camargo-Borges, } \\
\text { Pereira, Mishima, Kawata, Silveira and } \\
\text { Oliveira, } 2012^{(10)}\end{array}$ & "They constitute what is given, which is allowed and accepted". \\
\hline $\begin{array}{l}\text { Sanches, Couto, Abrahão and Andrade, } \\
\qquad 2013^{(19)}\end{array}$ & Norms, rules, regulations transmitted to groups. \\
\hline Depes and Pereira, $2013^{(20)}$ & $\begin{array}{c}\text { "Tree of logical compositions which, depending on their materialization and degree of formalization } \\
\text { adopted, can be laws or norms if described, or can be guidelines, regularities of behavior when they are } \\
\text { not stated in a manifest way." }\end{array}$ \\
\hline Silva, Gomes, Torres e Siniak, $2013^{(22)}$ & "Set of laws, rules and practices." \\
\hline $\begin{array}{l}\text { Lima, Severo, Andrade, Soares and Silva, } \\
\qquad 2013^{(21)}\end{array}$ & $\begin{array}{l}\text { "Dominant forces in our society, values, rules, made official or not, which are configured as a network, } \\
\text { a fabric of institutions." }\end{array}$ \\
\hline Silveira and Nunes, $2013^{(18)}$ & $\begin{array}{l}\text { "Institution as a social practice historically produced and made natural by an effect of forgetting the } \\
\text { power/knowledge practices." } \\
\text { "Institutions are vectors affecting the modes of existence that cross and are crossed by material bodies." }\end{array}$ \\
\hline
\end{tabular}

Continue.. 
..continuation

\begin{tabular}{|c|c|}
\hline \multicolumn{2}{|r|}{ INSTITUTION IS IMMATERIAL } \\
\hline Pezzato and L'Abbate, $2012^{(11)}$ & $\begin{array}{c}\text { "It is immaterial, it is never directly understandable. It can only be apprehended through the materiality } \\
\text { of the organization". }\end{array}$ \\
\hline Depes and Pereira, 2013 (20) & $\begin{array}{l}\text { Institution is abstract and is materialized by the organization and unfolds into smaller units } \\
\text { (establishments). }\end{array}$ \\
\hline Pezzato, L'Abbate and Botazzo, 2013 ${ }^{(17)}$ & "The institution is immaterial". "It can only be apprehended through the materiality of the organization". \\
\hline $\begin{array}{l}\text { Fortuna, Monceau, Valentim, Mennani, } \\
\qquad 2014^{(33)}\end{array}$ & $\begin{array}{l}\text { "They are abstract logics, but also material, resulting from a dialectical process consisting of a more } \\
\text { fixed part (the instituted), which is their most visible part, a mutable part (the instituting) that causes } \\
\text { ruptures with traditional pacts, and a third moment called institutionalization, in which the instituting is } \\
\text { incorporated by the institution and becomes instituted". }\end{array}$ \\
\hline \multicolumn{2}{|c|}{ INSTITUTION IS COMPOSED IN THREE MOMENTS: INSTITUTING, INSTITUTED AND INSTITUTIONALIZATION } \\
\hline Pezzato and L'Abbate, $2012^{(11)}$ & Result of the dynamic and dialectical movement between instituted, instituting and institutionalization. \\
\hline Pezzato, L'Abbate and Botazzo, 2013 $3^{(17)}$ & $\begin{array}{l}\text { "Dynamic and dialectical movement between three moments: the instituted, the instituting and the } \\
\text { institutionalization". }\end{array}$ \\
\hline $\begin{array}{l}\text { Spagnol, L'Abbate, Monceau and Jovic, } \\
2016^{(28)}\end{array}$ & "Concept dialectique." \\
\hline $\begin{array}{l}\text { Fortuna, Monceau, Valentim, Mennani, } \\
\qquad 2014^{(33)}\end{array}$ & $\begin{array}{l}\text { "They are abstract logics, but also material, resulting from a dialectical process consisting of a more } \\
\text { fixed part (the instituted) which is their most apparent part, a mutable part (the instituting) that causes } \\
\text { ruptures with traditional pacts, and a third moment called institutionalization, in which the instituting is } \\
\text { incorporated by the institution and becomes instituted". }\end{array}$ \\
\hline Garcia and L'Abbate, $2015^{(24)}$ & $\begin{array}{l}\text { "It is the result of the dynamic articulation between three moments: the instituted, the instituting and the } \\
\text { institutionalization". }\end{array}$ \\
\hline Garcia, L'Abbate, Arakaki, $2015^{(27)}$ & "Que reconoce três momentos de descomposición: instituído, instituyente, institucionalización." \\
\hline \multicolumn{2}{|c|}{ INSTITUTION IN ITS THREE MOMENTS: INSTITUTING, INSTITUTED AND INSTITUTION } \\
\hline Silva, Gomes, Torres and Siniak, 2013 $3^{(22)}$ & "Three moments: institution, instituted and instituting." \\
\hline \multicolumn{2}{|c|}{ INSTITUTION AS TWO MOMENTS: INSTITUTED AND INSTITUTING } \\
\hline Romagnoli and Magnani, $2012^{(8)}$ & "Field of forces of the instituted and the instituting". \\
\hline $\begin{array}{c}\text { Fortuna, Matumoto, Camargo-Borges, } \\
\text { Pereira, Mishima, Kawata, Silveira e } \\
\text { Oliveira, 2012 }\end{array}$ & Interplay between the instituting and the instituted. \\
\hline Archanjo e Schraiber, $2012^{(12)}$ & Constant movement between the instituted and the instituting. \\
\hline Silveira e Nunes, $2013^{(18)}$ & It has flows that move and/or conserve it. \\
\hline $\begin{array}{l}\text { Fortuna, Mesquita, Matumoto e } \\
\text { Monceau, } 2016^{(30)}\end{array}$ & $\begin{array}{c}\text { "A dynamic, they are always in motion, a game between maintenance and creation, conservation and } \\
\text { dissolution". }\end{array}$ \\
\hline Dóbies and L'Abbate, $2016^{(31)}$ & "Institutions are dialectically constituted by instituted and instituting moments". \\
\hline $\begin{array}{l}\text { Passos, Vieira, Moreira, Rodrigues, } \\
\text { Amorim, Santos, Abreu, Gomes, } \\
\text { Mendes, Lima, Moura, França, Ferraz, } \\
2017^{(32)}\end{array}$ & $\begin{array}{c}\text { "Paradigme institutionnel pour l'analyse des logiques sociales (les institutions) en intervenant sur le } \\
\text { fonctionnement collectif et sur les thématiques et procédés de recherche. Elle présente des concepts } \\
\text { pour la compréhension du fonctionnement de la réalité dans ses aspects contradictoires: les aspects } \\
\text { institués et anti-productifs et ceux instituants et productifs." }\end{array}$ \\
\hline \multicolumn{2}{|r|}{ INSTITUTION AS ORGANIZATION OR ESTABLISHMENT } \\
\hline Muniz, Tavares, $2012^{(16)}$ & Organization or establishment. \\
\hline \multicolumn{2}{|r|}{ INSTITUTION AS MULTIPLE CRYSTALLIZED MEANINGS } \\
\hline Zambenedetti and Silva, 2015 ${ }^{(29)}$ & Something that can be interrogated in its multiple crystallized meanings. \\
\hline \multicolumn{2}{|r|}{ LOGICAL BODIES OF MEANINGS } \\
\hline Barreto, Dimenstein and Leite, $2013^{(13)}$ & "Logical bodies of meanings". \\
\hline AUTHORS & INSTITUTED MOMENT \\
\hline \multicolumn{2}{|r|}{ DIALECTICAL FORCES } \\
\hline Romagnoli, 2015a $\mathrm{a}^{(9)}$ & "These are dialectical forces". \\
\hline Romagnoli, 2015b & "They are dialectical forces". \\
\hline \multicolumn{2}{|r|}{ VISIBLE PART OF THE INSTITUTION } \\
\hline $\begin{array}{l}\text { Fortuna, Monceau, Valentim, Mennani, } \\
\qquad 2014^{(33)}\end{array}$ & "The most fixed part (the instituted) that is their most visible part". \\
\hline \multicolumn{2}{|r|}{ PLAN OF FORMS ALSO CALLED ORGANIZATION PLAN } \\
\hline Romagnoli and Magnani, $2012^{(8)}$ & "The plan of forms, also called the organization plan, corresponds to what is socially instituted". \\
\hline \multicolumn{2}{|r|}{ CONSERVATIVE AND ESTABLISHED } \\
\hline Pezzato and L'Abbate, $2012^{(11)}$ & "What is set, established". \\
\hline Muniz, Tavares, $2012^{(16)}$ & The instituted is the fixed institution, it denies the social knowledge. It resists changes. \\
\hline Archanjo and Schraiber, $2012^{(12)}$ & $\begin{array}{l}\text { "What is given". "Established order according to the values and modes of representation of the } \\
\text { organization, considered normal. It corresponds to what is already known". }\end{array}$ \\
\hline Depes and Pereira, $2013^{(20)}$ & As conservative and established. \\
\hline Pezzato, L'Abbate and Botazzo, 2013 ${ }^{(17)}$ & Instituted moment that is set, established, norms and laws. \\
\hline $\begin{array}{l}\text { Zambenedetti, Piccinini, Sales, Paulon } \\
\text { and Silva, 2014 }\end{array}$ & "Crystallized aspects of reality". \\
\hline Garcia, L’Abbate and Arakaki, $2015^{(27)}$ & Refers to the established things. \\
\hline
\end{tabular}




\begin{tabular}{|c|c|}
\hline Dóbies and L'Abbate, $2016^{(31)}$ & $\begin{array}{l}\text { "The established order, the values, the modes of representation and organization, considered normal". } \\
\text { "The instituted depends on the instituting to make progress". }\end{array}$ \\
\hline $\begin{array}{c}\text { Fortuna, Mesquita, Matumoto and } \\
\text { Monceau, 2016 }\end{array}$ & $\begin{array}{c}\text { "Effect of instituting action and is imbricated with the equipment and its functions. It tends to reproduce } \\
\text { other instituted forms and maintain the order". }\end{array}$ \\
\hline \multicolumn{2}{|r|}{ NORMS AND LAWS } \\
\hline Pezzato and L'Abbate, $2012^{(11)}$ & Norms, laws, universal. \\
\hline Pezzato, L'Abbate and Botazzo, 2013 $3^{(17)}$ & Norms and laws. \\
\hline Silveira and Nunes, $2013^{(18)}$ & "From the norm, hegemonic in the asylum logic". \\
\hline Garcia, L'Abbate and Arakaki, 2015 (27) & \\
\hline \multicolumn{2}{|l|}{ Garcia, L'Abbate and Arakaki, $2015^{(27)}$} \\
\hline \multicolumn{2}{|r|}{ "Los conocimientos y la práctica." } \\
\hline \multicolumn{2}{|r|}{ INCESSANT REPRODUCTION } \\
\hline $\begin{array}{c}\text { Fortuna, Matumoto, Camargo-Borges, } \\
\text { Pereira, Mishima, Kawata, Silveira and } \\
\text { Oliveira, } 2012^{(10)}\end{array}$ & "Incessant (instituted) reproduction". \\
\hline \multicolumn{2}{|r|}{ GAMES OF FORCE THAT TRY TO PRODUCE IMMOBILITY } \\
\hline Archanjo and Schraiber, $2012^{(12)}$ & "Games of force that try to produce immobility [...] in constant contradiction with instituting forces". \\
\hline $\begin{array}{c}\text { Passos, Vieira, Moreira, Rodrigues, } \\
\text { Amorim, Santos, Abreu, Gomes, } \\
\text { Mendes, Lima, Moura, França, Ferraz, } \\
2017^{(32)}\end{array}$ & "Aspects institués et anti-productifs." \\
\hline \multicolumn{2}{|r|}{ CONTINUING EDUCATION } \\
\hline Muniz, Tavares, 2012(16) & $\begin{array}{l}\text { "The spaces for continuing education must become instituted, guaranteed and supported in their } \\
\text { instituting potential to subsidize changes". }\end{array}$ \\
\hline \multicolumn{2}{|r|}{ HIERARCHIZED, VERTICAL AND FUNCTIONAL } \\
\hline Silva, $2015^{(26)}$ & Hierarchized, vertical and functional. \\
\hline AUTHORS & INSTITUTING MOMENT \\
\hline \multicolumn{2}{|r|}{ PRESSURES EXERTED } \\
\hline $\begin{array}{l}\text { Sanches, Couto, Abrahão and Andrade, } \\
2013^{(19)}\end{array}$ & "Pressures exerted by groups or individuals". \\
\hline Romagnoli, $2015 \mathrm{a}^{(9)}$ & "These forces are dialectical". \\
\hline Romagnoli, 2015b $\mathrm{b}^{(25)}$ & They are dialectical forces. \\
\hline \multicolumn{2}{|r|}{ PRODUCTIVE AND INNOVATIVE FORCE } \\
\hline Gontijo, Xavier and Freitas, $2012^{(15)}$ & $\begin{array}{l}\text { "The instituting ideas are innovative that provide changes or improvements in technologies or in social } \\
\text { reorganization". They also bring the implementation of the kangaroo method as an instituting force. }\end{array}$ \\
\hline $\begin{array}{l}\text { Pereira, Ribeiro, Santos and Depes, } \\
\qquad 2012^{(14)}\end{array}$ & $\begin{array}{l}\text { Potential, transforming. "New, the motivation". "It always conveys a dynamic, changeable and mutant } \\
\text { characteristic. Where the new insinuates itself and reaffirms itself". "Transforming, creative and } \\
\text { revolutionary side. [...] It is informed by the instituted that generates it, that makes it appear and then, } \\
\text { ends up being regenerated by it (instituted). Thus, both are necessary and neither exists without its } \\
\text { opposite, they are complementary, they live in an always unstable balance". }\end{array}$ \\
\hline Muniz, Tavares, $2012^{(16)}$ & "Opening escape lines, operating innovative practices". \\
\hline Archanjo and Schraiber, 2012 $2^{(12)}$ & "Renovation, urging creative processes". "Capacity for innovation." \\
\hline Depes and Pereira, 2013 201 & $\begin{array}{l}\text { "Productive/innovative forces that tend to be the foundation of institutions". "Final effect, exhausted } \\
\text { from the instituting activity". }\end{array}$ \\
\hline $\begin{array}{c}\text { Zambenedetti, Piccinini, Sales, Paulon } \\
\text { and Silva, 2014 }\end{array}$ & "It refers to the movement, the possibility of creating new meanings, strategies and solutions". \\
\hline Dóbies and L'Abbate, $2016^{(31)}$ & "Capacity for innovation". \\
\hline $\begin{array}{c}\text { Fortuna, Mesquita, Matumoto and } \\
\text { Monceau, 2016 } \\
\end{array}$ & Creation. \\
\hline $\begin{array}{c}\text { Passos, Vieira, Moreira, Rodrigues, } \\
\text { Amorim, Santos, Abreu, Gomes, Mendes, } \\
\text { Lima, Moura, França, Ferraz, 2017(32) }\end{array}$ & "Aspects instituants et productifs." \\
\hline \multicolumn{2}{|r|}{ DENIAL OF THE INSTITUTED, THE CONTESTATION } \\
\hline Pezzato and L'Abbate, $2012^{(11)}$ & $\begin{array}{l}\text { "It expresses the particularity, the denial of the instituted, of the universal, the contestation, the questioning } \\
\text { of the instituted by the project of what is not yet but can come to be". "Unshaping everyday life" }\end{array}$ \\
\hline Archanjo and Schraiber, $2012^{(12)}$ & "Represent contestation". \\
\hline Pezzato, L'Abbate and Botazzo, $2013^{(17)}$ & "The denial of the instituted, the contestation". \\
\hline Silva, Gomes, Torres and Siniak, 2013 ${ }^{(22)}$ & "As the transformer/questioner of this process". \\
\hline Silveira and Nunes, $2013^{(18)}$ & $\begin{array}{l}\text { "Subversive, counter-hegemonic, being able to radicalize the production of new encounters with } \\
\text { madness and the madman". }\end{array}$ \\
\hline Garcia and L'Abbate, 2015 (24) & "The instituting denies the instituted in the opposite meaning to the idea of renovation/innovation". \\
\hline Garcia, L'Abbate and Arakaki, 2015 (27) & Denies the instituted. \\
\hline Dóbies and L'Abbate, $2016^{(31)}$ & Contestation. \\
\hline \multicolumn{2}{|c|}{ INSTITUTING MAY BE CONSERVATIVE IN RELATION TO THE INSTITUTED } \\
\hline Garcia and L'Abbate, $2015^{(24)}$ & "The instituting can be conservative in relation to the instituted". \\
\hline
\end{tabular}




\begin{tabular}{|c|c|}
\hline $\begin{array}{l}\text { Fortuna, Camargo-Borges, Pereira, } \\
\text { Mishima, Kawata, Silveira and Oliveira, } \\
2012^{(10)}\end{array}$ & "Movements of change (instituting)." \\
\hline Muniz, Tavares, $2012^{(16)}$ & $\begin{array}{l}\text { "The instituting is the movement for changes in the institution. In other words, the instituting breaks with } \\
\text { the instituted in search of free subjectification". }\end{array}$ \\
\hline Silva, Gomes, Torres and Siniak, 2013 (22) & "The act of transformation and self-management of a subject belonging to an institution". \\
\hline $\begin{array}{l}\text { Fortuna, Monceau, Valentim, Mennani, } \\
\qquad 2014^{(33)}\end{array}$ & "A changing part (the instituting) that causes ruptures with traditional pacts". \\
\hline $\begin{array}{l}\text { Fortuna, Mesquita, Matumoto and } \\
\text { Monceau, } 2016^{(30)}\end{array}$ & "The transformation processes". \\
\hline \multicolumn{2}{|r|}{ THE NEW, THE STRANGE, THE UNKNOWN } \\
\hline Archanjo and Schraiber, 2012 $2^{(12)}$ & $\begin{array}{l}\text { "It corresponds to the new, the strange, the unknown". "Mobilizers of reflection and criticism regarding } \\
\text { their practices and assumptions (psychologists)". }\end{array}$ \\
\hline \multicolumn{2}{|r|}{ THE CRISIS } \\
\hline Silveira and Nunes, $2013^{(18)}$ & $\begin{array}{c}\text { The crisis (madness) covers and reveals the instituting power that speaks of the lack of strength of the } \\
\text { instituted. }\end{array}$ \\
\hline AUTHORS & INSTITUTIONALIZATION MOMENT \\
\hline \multicolumn{2}{|r|}{ GAME BETWEEN THE INSTITUTED AND THE INSTITUTING } \\
\hline Pezzato and L'Abbate, $2012^{(11)}$ & $\begin{array}{l}\text { "The result of the relationship between two moments - instituted and instituting - Is institutionalization, the } \\
\text { moment of singularity, that is, metastable balance in perpetual becoming and not definitive synthesis". } \\
\text { Virtual object produced by the analysis that elaborates it, while interpreting it at the same time. }\end{array}$ \\
\hline Archanjo and Schraiber, $2012^{(12)}$ & $\begin{array}{l}\text { "Permanent struggle between the instituted-instituting, all are somehow involved and assume a position } \\
\text { and role that contribute to the institution always being an open field, in which forces coming from } \\
\text { multiple directions interact, negotiate and, at times, have tension between themselves". }\end{array}$ \\
\hline Pezzato, L'Abbate and Botazzo, 2013 $3^{(17)}$ & "The result of the relationship between instituted and instituting". "The singularity, the balance". \\
\hline $\begin{array}{l}\text { Fortuna, Monceau, Valentim, Mennani, } \\
\qquad 2014^{(33)}\end{array}$ & $\begin{array}{l}\text { "Third moment called institutionalization in which the instituting is incorporated by the institution and } \\
\text { becomes instituted". }\end{array}$ \\
\hline Romagnoli, $2015 \mathrm{a}^{(9)}$ & "It will sustain exactly the conflict of institutional forces between the instituted and the instituting". \\
\hline Garcia and L'Abbate, $2015^{(24)}$ & $\begin{array}{l}\text { "It implies duration, temporality and historicity". } \\
\text { "The permanent confrontation between the instituted (that which seeks to maintain) and the instituting } \\
\text { (forces of subversion and change)". }\end{array}$ \\
\hline Garcia, L'Abbate, Arakaki, 2015 (27) & Moment of synthesis between instituted and instituting. \\
\hline \multicolumn{2}{|r|}{ PROCESS BY WHICH THE INSTITUTION PRODUCES ITSELF } \\
\hline Muniz, Tavares, $2012^{(16)}$ & "It is continuity, not interruption" \\
\hline Dóbies and L'Abbate, $2016^{(31)}$ & $\begin{array}{l}\text { "The process by which the institution produces itself is not always positive to the extent that each } \\
\text { institution lives with its denial all the time". }\end{array}$ \\
\hline
\end{tabular}

\section{DISCUSSION}

The concept of institution in its three moments was analyzed in the present study, in the perspective of a tool-concept, that is, which aims to understand how to operate the concept and perceive it as life in movement that expands the experimentation possibilities, a tool to live the concept ${ }^{(34)}$.

The results showed that in some studies, approximations were established with the IA framework without opting for specific affiliation to its aspects. In other studies, the concepts of Socioanalysis or Schizoanalysis were followed exclusively without crossing them. In a third group, the lines of Socioanalysis and Schizoanalysis were approximated. In Brazil, there is disagreement between the approximation of aspects of IA. Some authors claim there are epistemological differences between them but choose to bring concepts together by understanding that they coexist and dialogue with each other to intervene. They are: institution - instituted, instituting and institutionalization - implication, analyzer, flows, forces, agencies, control, territorialization and deterritorialization. Institutional Analysis is inserted in the institutionalist movement, constituted by "a heterogeneous, heterological and polymorphic set of guidelines, among which a common characteristic can be found: its aspiration to trigger, support and improve self-analytical and self-managing processes of social collectives"(35). However, although the two strands come from the same social genesis - May 68 in France - other authors discuss important differences in the theoretical genesis between them ${ }^{(4)}$, known as mixture (mélange), which is how these productions are called.

The analyzed studies made use of several IA works and authors for their theoretical and methodological foundation. In the first choice, the 'Compendium of Institutional Analysis' (35) was used and, subsequently, the 'Institutional Analysis' book ${ }^{(1)}$. Perhaps the choice for the first work is linked to the more understandable form of writing, especially for readers approaching the theme for the first time. The 'Institutional Analysis' work discusses the concept of institution by crossing several theoretical perspectives of the social sciences and is a rich but dense text for an initial reading. Six years after writing, the author declared that "under the pretext of theorization, generalization, conceptual ordering, I wrote a cold book on a scorching subject" ${ }^{\prime \prime 1}$.

The Institution concept was analyzed in this integrative review, since this is a central aspect of the IA theoretical framework, as described in Chart 3. In the studies analyzed, it varied according to the need of the topic in question, which demonstrated the multiplicity of uses and modes to operate health practices and confirmed the polysemy 
around the concept and object under analysis. Most modes and uses were close to René Lourau's perspective. For IA, the institution has a visible dimension that materializes in the organization and/or establishment, and an immaterial dimension constituted by norms, rules and laws including the way how individuals agree or not, to participate in these same norms $s^{(1-2,36)}$.

In IA, the concept of institution is linked to the Hegelian dialectic perspective, consisting of three moments: instituted (thesis), instituting (antithesis) and institutionalization (synthesis $)^{(1-2,36-38)}$. The traditional Greek dialectic, the Platonic dialectic, comprised two moments, a duality with the exclusion character (two opposites). The addition of the third moment proposed in the Hegelian dialectic aimed at the character of overcoming and conservation in the search for a synthesis between opposites, where the thesis accommodates or not the antithesis in infinite movements of negation and accommodation that constitute the Hegelian system ${ }^{(39)}$. In Hegelian logic, "dialectics obliges us not to be content with the dualistic opposition between particular interests and general interest. The universality of the institution, through the mediation of each particular case, is embodied in singular and differentiated forms"(38).

Considering the polysemy of the institution concept and from the varied modes and uses in the studies analyzed (Chart 3), at times taken in their immaterial dimension, at other times taken in their dimension of rules, norms and laws, and at other times being the two moments, there are many analysis possibilities. The game between instituting versus instituted may or may not result in accommodation and conservation and may be refuted or accepted in the institutionalization process, which does not invalidate studies that demonstrate only one or another moment of the concept, as long as the operation process appears. Institutional Analysis is considered a dynamic and instituting theoretical contribution. Its concepts can be directed to operate social practices that transform them while transforming realities.

However, some authors point out the polysemic character of the concept and refer that isolating the instituted is restricting to the transcendent positivist conception of the institution regarding real social relationships. To isolate the instituting, a tendency of economism and subjectivism (group psychology), is to fall into a phenomenologist and psychologist view. To isolate institutionalization, as done in the sociology of organizations and in organizational ideology in general, is to make the rationality and positivity of social forms autonomous, to the detriment of history, contradictions and class struggle ${ }^{(2)}$. In other words, in order to capture the institutionalization process of every institution, it becomes "impossible to isolate any one of the three moments" ${ }^{(4)}$.

On the other hand, some authors mention the creative way in which the strands of IA are approximated ${ }^{(35)}$ - Socioanalysis and Schizoanalysis - and the concepts are operated in Brazil. The Brazilian IA is historically marked by the hybridism between the French Socioanalysis strand and the Latin American production about groups - especially the Operative Group - that integrates the institutionalist movement, constituting what is called a "heterogeneous marriage" ${ }^{(40)}$.

There was an interesting variability in the study objects that chose the IA, as shown in Chart 2. However, some study objects in the health field were little explored, such as the hospital area, which was addressed in only three stu$\operatorname{dies}^{(15-16,19)}$. The IA framework was more used in studies related to Public Health and Mental Health.

The institutions that crossed the objects of study explicitly were education (university, research, school) ${ }^{(8,10,33)}$, the group ${ }^{(10)}$, health ${ }^{(10)}$, the technical and social division of labor ${ }^{(10)}$, the justice ${ }^{(10)}$ and parenting ${ }^{(33)}$. In other investigations, the institutions appeared implicitly, such as in health professions, beliefs/religions, the family, sexism and/ or patriarchal society, death and the biomedical model of healthcare.

In the various study objects analyzed, the research institution, for example, was put under analysis by questioning the methodological procedure - techniques and/or tools, the crystallized places of the researcher, neutrality and the idea of interviewer's non-interference in data production, the lack of experience and skill of researchers, and the time limit and research schedule frequently imposed by research agencies and foundations in the country. These questions explain the instituted form of this institution and cross the analyzed study objects. In this sense, IA interrogates the instituted and hegemonic modes of knowledge production by putting into play the possibility of creative and more flexible arrangements, being itself the instituting of the research institution.

As shown in Chart 3, the most analyzed moment of the institution concept was the instituted. The rules and laws were repeated at the institution and the instituted moment, demonstrating that authors chose to use one of several dimensions of the concepts. Thus, "it is considered that the instituted contemplates the social forms installed, recognized and validated socially; in the 'instituted' we will place not only the established order, values, modes of representation and organization considered normal, but also the usual forecasting procedures (economic, social and political)"(37-38). A conceptual mistake that may occur in the operation of this concept is to think of it as something bad that should always be replaced by another new social practice, as if the "new" and the change were always better than the "old". The "way of analyzing the institutions brought some difficulties for the IA, especially in identifying the instituting with the 'good' and the instituted with the "bad"'(4). The substitution of social practices instituted by other instituting, among which health practices, demands having the health needs of people and communities as the centrality. Thus, the operation of IA concepts is aimed at interrogating which objectives such practices wish to establish, which society projects are being implemented and to whom they are interesting. Therefore, the instituted can represent something better than the instituting and vice versa, depending on the point of view of the analysis and the object in question.

The second moment of the concept of institution, the Instituting, is described in Chart 3. It consists of marginal social forces that may or may not be recognized by 
the installed social forms, which is not necessarily good or bad in relation to the instituted. "By 'instituting', we will understand, at the same time, contestation, the capacity for innovation and, in general, the political practice as 'signifier' of social practice"(37). In the study objects analyzed, the instituting processes that questioned the instituted stood out. In this way, the operation of the moment could contribute to maintain instituted health practices and/or modify those that were not aligned with assumptions of institutions under analysis.

The third analyzed moment of the institution concept was Institutionalization, as described in Chart 3, which was the least highlighted in the studies. This third moment incorporates the existence of two other moments within the institutionalization: the founding institutionalization, understood as the initial moment of creation of the institution and when it takes shape; and the permanent institutionalization, which consists in updating and resuming its purpose of functioning throughout time, whether or not towards its creation purpose $^{(41)}$. It is the process by which the institution legitimates itself and remains or not, over time, and consists of successive transformation processes that make its existence lasting or ephemeral. The analysis of successive institutionalization processes is essential. They reveal the capacity for adjustments, refinements, and integration of their contradictions ${ }^{(42)}$. For IA, the more transformations of accommodation of the instituting by the instituted, the more lasting the institution becomes. Institutionalization is the third moment in Hegel's dialectic, "it is up to the moment of singularity - moment of integration - in singular forms of organization, management, administration, functioning - to ensure the institutional implication of each individual constituting society. In this sense, the negative unity of social forms, always in an unstable balance, makes singularity the moment of regulation"(37). An example of a long institutionalization process is that of the Catholic Church: with more than two thousand years of existence, it was one of the objects of study of $\mathrm{IA}^{(1)}$.

The IA concepts added knowledge for the areas of nursing and psychology, the two that most published works using this theoretical-methodological framework in the health field. Several objects of study analyzed are priority themes for the areas of health and nursing, and they could be questioned in order to know if the perspectives they met were consistent or not with the principles and guidelines of the SUS. In this way, the IA contributed to analyze the instituted social forms, their modes of operation, the instituting movements, and the most present institutions that have crossed the field of health and nursing, as well as their institutionalization processes.
Within the limits of this study, the expressive number of publications in the last five years stood out. This fact increased the curiosity of knowing other ways of putting IA into action that did not constitute research. The production of new reviews is recommended in order to know the scenario of theses, dissertations, interventions, among others, and expand the knowledge of experiences acquired with the theme in Brazil.

\section{CONCLUSION}

The scenario found showed that the theoretical-methodological framework of IA offers consistency for the analysis of objects of health studies crossed by a complex and interconnected network of institutions, broadening this concept. The concept of institution in its three moments - instituted, instituting, institutionalization - under analysis in this integrative review, proved to be a tool-concept of interrogating health practices for understanding them better.

The multiple forms found in the use of concepts referred to a creative and interesting polysemy, with studies that approached René Lourau's perspective but revealed an open and instituting paradigmatic perspective of producing knowledge and health practices, which allows approximating concepts and favoring the production of new modes of functioning of institutions.

Neither the creation of new concepts nor that of misconceptions was found. In this analysis, the most distant of all referred to the understanding of "institution" as an organization or establishment. This perspective distances itself from the conception supported especially in the postulate by this referential. The polysemic form approached by the different researchers may be connected to the relation of such concepts to their objects of study, which may have led them to reinforce a certain facet of the institution concept or its movements (instituted, instituting and institutionalization). A partial or total adoption of IA concepts was identified in the articles, sometimes supported by the framework of socioanalysis and sometimes by schizoanalysis.

Given that Institutional Analysis constitutes a multi-referential theoretical framework, most objects of study that chose it dialogued with the field of public health, especially with the nuclei of knowledge from social sciences and management.

The study revealed that, in the area of health, nursing and psychology have adopted this theoretical-methodological framework and contributed to interrogate objects of study of priority themes by adding knowledge and proposing health practices more aligned with the principles and guidelines of the SUS.

\section{RESUMO}

Objetivo: Analisar, nos estudos da área da saúde, a utilização do referencial teórico-metodológico da Análise Institucional e do conceito central de instituição em seus três momentos - instituído, instituinte e institucionalização. Método: Revisão integrativa realizada nas bases PubMed/Medline, LILACS, Scopus, CINAHL, sendo incluídos na busca artigos originais de pesquisa, publicados entre 2012 e 2017. Resultados: Foram analisadas 26 publicações. Encontrou-se uma pluralidade de objetos de estudo, sendo mais comuns os relacionados à saúde coletiva: saúde mental, violência, relação família-equipe, saúde da família, atenção primária, saúde da mulher, infância e adolescência, saúde bucal, educação permanente, micropolítica do trabalho em saúde, vigilância em saúde, HIV, direito, práticas pedagógicas, educação escolar e Autismo. A enfermagem e a psicologia foram as áreas que mais optaram pela Análise Institucional. A polissemia do conceito de instituição se confirma nos achados, indicando uma riqueza nos modos e usos dos conceitos. Conclusão: A Análise Institucional apresenta conceitos-ferramenta capazes de operar análises de práticas em saúde condizentes com o Sistema Único de Saúde. 


\section{DESCRITORES}

Análise Institucional; Organizações; Saúde Pública; Técnicas de Pesquisa; Revisão.

\section{RESUMEN}

Objetivo: Analizar, en los estudios del área sanitaria,la utilización del marco de referencia teórico metodológico del Análisis Institucional y del concepto central de institución en sus tres momentos - instituido, instituyente e institucionalización. Método: Revisión integradora llevada a cabo en las bases de datos PubMed/Medline, LILACS, Scopus, CINAHL, incluyéndose en la búsqueda artículos originales de investigación, publicados entre 2012 y 2017. Resultados: Fueron analizadas 26 publicaciones. Se encontró una pluralidad de objetos de estudio, siendo los más comunes los relacionados con la salud colectiva: salud mental, violencia, relación familia-equipo, salude de la familia, atención primaria, salud de la mujer, infancia y adolescencia, salud bucal, educación permanente, micropolítica del trabajo en salud, vigilancia en salud, VIH, derecho, prácticas pedagógicas, educación escolar y Autismo. La enfermería y la psicología fueron las áreas que más optaron por el Análisis Institucional. La polisemia del concepto de institución se confirma en los hallazgos, señalando una riqueza en los modos y usos de los conceptos. Conclusión: El Análisis Institucional presenta conceptos herramienta capaces de operar análisis de prácticas en salud acordes con el Sistema Único de Salud.

\section{DESCRIPTORES}

Análisis Institucional; Organicaciones; Salud Pública; Técnicas de Investigación; Revisión.

\section{REFERENCES}

1. Lourau R. A Análise institucional. $3^{\text {a }}$ ed. Petrópolis: Vozes; 2014.

2. Lourau R, Lapassade G. Chaves da sociologia. Rio de Janeiro: Civilização Brasileira; 1972.

3. Rodrigues HBC. Análise Institucional francesa e transformação social: o tempo (e contratempo) das intervenções. Acheront [Internet]. 2004 jul [citado 2010 nov. 02];19. Disponível em: //www.acheronta.org/acheronta18/barrosconde.htm

4. L'Abbate S. Análise institucional e saúde coletiva: uma articulação em processo. In: L'abbate S, Mourão LC, Pezzato LM, organizadores. Análise institucional e saúde coletiva. São Paulo: Hucitec; 2013. p.31-88.

5. Rodrigues, HBC. As subjetividades em revolta: institucionalismo francês e novas análises [dissertação]. Rio de Janeiro: Universidade do Estado do Rio de Janeiro, Instituto de Medicina Social; 1993.

6. Soares CB, Hoga LAK, Peduzzi M, Sangaleti C, Yonekura T, Silva DRAD. Integrative Review: concepts and methods used nursing. Rev Esc Enferm USP. 2014;48(2):335-45. DOI: http://dx.doi.org/10.1590/S0080-6234201400002000020

7. Brasil. Ministério da Saúde; Secretaria de Gestão do Trabalho e da Educação na Saúde, Departamento de Gestão e da Regulação do Trabalho em Saúde. Câmara de regulação do trabalho em saúde [Internet]. Brasília; 2006 [citado 2017 nov. 01]. Disponível em: http:// bvsms.saude.gov.br/bvs/publicacoes/cart_camara_regulacao.pdf.

8. Romagnoli RC, Magnani NR. Nós e linhas: pesquisando a relação familia e equipe. Fractal Rev Psicol. 2012;24(2):287-306. DOI: http:// dx.doi.org/10.1590/S1984-02922012000200006

9. Romagnoli RC. A violência contra a mulher em Montes Claros. Barbar [Internet].2015 [citado 2017 nov. 01];43:27-47. Disponível em: https://online.unisc.br/seer/index.php/barbaroi/article/view/4815/4407

10. Fortuna CM, Matumoto S, Camargo-Borges C, Pereira, MJB, Mishima SM, Kawata LS, et al. Cartographic notes on the work in the family health strategy: relationships between workers and the population. Rev Esc Enferm USP. 2012;46(3):657-64. DOI: http://dx.doi. org/10.1590/S0080-62342012000300018

11. Pezzato LM, L'Abbate S. A intervention-research-action in collective oral health: contributing to new analyses production. Saúde Soc. 2012;21(2):386-98. DOI: http://dx.doi.org/10.1590/S0104-12902012000200012

12. Archanjo AM, Schraiber LB. The practice of psychologists in primary care units in the city of São Paulo. Saúde Soc. 2012;21(2):351-63. DOI: http://dx.doi.org/10.1590/S0104-12902012000200009

13. Barreto L, Dimenstein M, Leite JF. Attention to women in gender violence situation with demands in mental health. Athen Digital. 2013;13(3):195-207 DOI: http://dx.doi.org/10.5565/rev/athenead/v13n3.1155

14. Pereira WR, Ribeiro MRR, Santos NC, Depes VBS. Pedagogical practices, processo of subjectification and desire to learn from the institutionalist perpective. Acta Paul Enferm. 2012;25(6):962-8. DOI: http://dx.doi.org/10.1590/S0103-21002012000600021

15. Gontijo TL, Xavier CC, Freitas MIF. Evauation of the implementation of kangaroo care by health administrators, professionals, and mothers of newborn infants. Cad Saúde Pública. 2012;28(5):935-44. DOI: http://dx.doi.org/10.1590/S0102-311X2012000500012

16. Muniz MP, Tavares CMM. Understanding the nursing team on the educational processo of a psychiatric hospital. Rev Pesq Cuid Fundam Online. 2012;4(2):2883-97. DOI: http://dx.doi.org/10.9789/2175-5361

17. Pezzato LM, L'Abbate S, Botazzo C. The production of micro-policies in the work process in oral health: a sócio-analytical approach. Ciênc Saúde Coletiva. 2013;18(7):2095-104. DOI: http://dx.doi.org/10.1590/S1413-81232013000700025

18. Silveira L, Nunes MO. Para além e aquém de anjos, loucos ou demônios: CAPS e pentecostalismo em análise. Rev Police Psique. 2013;3(1). DOI: https://doi.org/10.22456/2238-152X.41767

19. Sanches ICP, Couto IRR, Abrahão AL, Andrade M. Hospital treatment: right or concession to the hospitalized user? Ciênc Saúde Coletiva. 2013;18(1):67-76. DOI: http://dx.doi.org/10.1590/\$1413-81232013000100008

20. Depes VBS, Pereira WR. Mobilization of scientific knowledge by graduates of a nursing master's degree. Rev Gaúcha Enferm. 2013;34(4):8490. DOI: http://dx.doi.org/10.1590/S1983-14472013000400011

21. Lima AIO, Severo AK, Andrade NL Soares GP, Silva LM. O desafio da construção do cuidado integralem saúde mental no âmbito da atenção primária. Temas Psicol. 2013;21(1):71-82. DOI: http://dx.doi.org/10.9788/TP2013.1-05 
22. Silva AB, Gomes BCF, Torres OM, Siniak DS. Matrix support and integral care networks in mental health. Rev Pesq Cuid Fundam Online. 2013;5(2):3655-66. DOI: http://dx.doi.org/10.9789/2175-5361

23. Zambenedetti G, Piccinini CA, Sales ALLF, Paulon SM, Silva RAN. Psicologia e análise institucional: contribuições para os processos formativos dos Agentes Comunitários de Saúde. Psicol Ciênc Prof. 2014;34(3):690-703. DOI: http://dx.doi.org/10.1590/19823703001302013

24. Garcia RA, L'Abbate S. Institucionalização da Vigilância em Saúde de Campinas (SP) na perspectiva da análise institucional sócio-histórica. Saúde Debate. 2015;39(107):997-1007. DOI: http://dx.doi.org/10.1590/0103-110420151070531

25. Romagnoli RC.Várias Marias: efeitos da Lei Maria da Penha nas delegacias. Fractal Rev Psicol. 2015;27(2):114-22. DOI: http://dx.doi. org/10.1590/1984-0292/1038

26. Silva DCR. Medicalização e controle na educação: o autismo como analisador das práticas inclusivas. Psicol Educ. 2015;41:109-17. DOI: http://dx.doi.org/10.5935/2175-3520.20150018

27. Garcia RA, L'Abbate S, Arakaki J. Estrategias de articulación entre Atención Primaria y Vigilancia em Salud y la interfaz entre los sujetos. Interface (Botucatu). 2015;19(54):431-42. DOI: http://dx.doi.org/10.1590/1807-57622014.0185

28. Spagnol CA, L'Abbate S, Monceau G, Jovic L. Dispositif socianalytique: instrument d'intervention et de collecte de données em recherche qualitative em soins infirmiers. Recherche Soins Infirmiers. 2016;1(124):108-17.

29. Zambenedetti G, Silva RAN. O paradoxo do território e os processos de estigmatização no acesso ao diagnóstico do HIV na atenção básica em saúde. Estud Psicol (Natal). 2015;20(4):229-40. DOI: http://dx.doi.org/10.5935/1678-4669.20150024

30. Fortuna CM, Mesquita LP, Matumoto S, Monceau G. A análise de implicação de pesquisadores em uma pesquisa-intervenção na Rede Cegonha: ferramenta da análise institucional. Cad Saúde Pública. 2016;32(9):e00117615. DOI: http://dx.doi.org/10.1590/0102$311 \times 00117615$

31. Dobies DV, L'Abbate S. A resistência como analisador da saúde mental em Campinas (SP): contribuições da Análise Institucional. Saúde Debate. 2016;40(110):120-33. DOI: http://dx.doi.org/10.1590/0103-1104201611009

32. Passos ICF, Vieira K, Moreira L, Rodrigues F, Amorim M, Santos C, et al. La promotion de la santé mentale des enfants et adolescents en situation de vulnérabilité et violence sociale: les défis pour un réseau intersectoriel. Érudit [Internet]. 2017 [cité 2017 nov. 01];42(1). Disponible en: https:/www.erudit.org/fr/revues/smq/2017-v42-n1-smq03101/1040257ar/.

33. Fortuna CM, Monceau G, Valentim S, Mennani KLE. Uma pesquisa socioclínica na França: notas sobre a análise institucional. Fractal Rev Psicol. 2014;26(2):255-66. DOI: http://dx.doi.org/10.1590/1984-0292/1309

34. Abrahão AL, Merhy EE. Health training and micropolitics: concept tools in teaching practices. Interface (Botucatu). 2014;18(49):313-24 DOI: http://dx.doi.org/10.1590/1807-57622013.0166

35. Baremblit GF. Compêndio de análise institucional e outras correntes: teoria e prática. $5^{\text {a }}$ ed. Belo Horizonte: Instituto Félis Guattari; 2002.

36. Lourau R. L'instituant contre l'institué. Paris: Anthropos; 1969.

37. Lourau R. Objeto e método da análise institucional. In: Altoé S. Analista institucional em tempo integral. São Paulo: Hucitec; 2004.

38. Lourau R. O instituinte contra o instituído. In: Altoé S. Analista institucional em tempo integral. São Paulo: Hucitec; 2004.

39. Hegel GWF. Enciclopédia das ciências filosóficas em compêndio 1830. v.1: A ciência da lógica. São Paulo: Loyola; 2007.

40. Rodrigues HBC, Barros, RDB. Socioanalise e práticas grupais no Brasil: um casamento de heterogêneos. Psicol Clín, 2003;15(1):55-70.

41. Savoye A. Análise institucional e pesquisas sócio-históricas: estado atual e novas perspectivas. Mnemosine [Internet]. 2007 [citado 2018 mar. 09];3(2):181-93. Disponível em: http://www.mnemosine.com.br/ojs/index.php/mnemosine/article/view/123/pdf_110.

42. Monceau G. Pratiques socianalytiques et sócio-clinique intitutionnelle. L'Homme Société [Internet]. 2003 [cité 2018 mar. 09];1(147):1133. Disponible en: https:/www.cairn.info/revue-l-homme-et-la-societe-2003-1-page-11.htm

Financial support:

Fundação de Amparo à Pesquisa do Estado de São Paulo (FAPESP). Technical Training Scholarship 3. 